\title{
Species of the genus Eimeria (apicomplexa: Eimeriidae) from japanese quails (Coturnix japonica) in Brazil and E. fluminensis for the preoccupied $E$. minima of this quail ${ }^{*}$
}

\author{
Espécies do gênero Eimeria (apicomplexa: Eimeriidae) em codornas \\ japonesas (Coturnix japonica) no brasil e Eimeria fluminensis para a \\ pré-ocupada $E$. minima desta codorna
}

\author{
Marcel Teixeira, ${ }^{\star \star}$ Carlos Wilson Gomes Lopes ${ }^{\star \star \star}$
}

\begin{abstract}
Fecal samples from 120 Japanese quails were submitted to centrifuge-flotation technique with saturated sugar solution in order to identify how many species of the genus Eimeria should be found in these birds in a breeding localized in the State of Rio de Janeiro, Brazil. Four distinct species were identified as Eimeria bateri Bhatia, Pandey and Pande, 1965 with diameters of the oocysts varied from $22.28 \pm 2.70$ to $18.38 \pm 2.50 \mu \mathrm{m}$; E. uzura Tsunoda and Muraki, 1971 from $20.82 \pm 1.78$ to $16.70 \pm 1.34 \mu \mathrm{m} ; E$. tsunodai Tsutsumi, 1972 from $19.85 \pm 1.93$ to $15.55 \pm 1.50 \mu \mathrm{m}$, and E. fluminensis for the pre-occupied E. minima Teixeira and Lopes, 2000 of the Japanese quail from $17.31 \pm 1.87$ to $16.45 \pm 1.72 \mu \mathrm{m}$. A description of each species were done based on morphological aspects of their oocysts after leaving them to sporulate in $2.5 \%$ potassium dichromate solution at $27^{\circ} \mathrm{C}$.
\end{abstract}

Keywords: oocysts; Eimeria bateri; Eimeria uzura; Eimeria tsunodai; Eimeria fluminensis; Apicomplexa; Eimeriidae; Japanese quail; Coturnix japonica; Rio de Janeiro, Brazil.

\section{Resumo}

Amostras de fezes de 120 codornas japonesas de uma criação localizada no estado do Rio de Janeiro, Brasil, foram submetidas à técnica de centrífugo-flotação em solução saturada de açúcar para identificar quantas espécies do gênero Eimeria possam ser encontradas parasitando codornas. Quatro espécies distintas foram identificadas como Eimeria bateri (Bhatia, Pandey e Pande, 1965), onde os oocistos mediam 22,28 22,70 por $18,38 \pm 2,50 \mu \mathrm{m}$; E. Uzura Tsunoda and Muraki, $1971 \mathrm{com}$

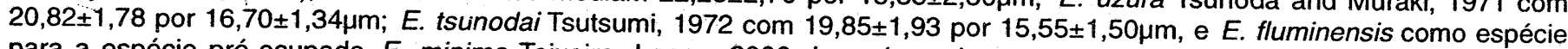

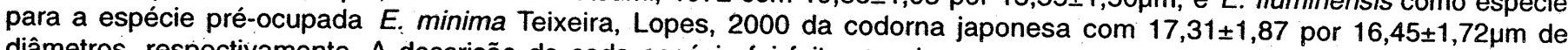
diâmetros, respectivamente. A descrição de cada espécie foi feita com base nos aspectos morfológicos dos oocistos, após esporulação em uma solução de $2,5 \%$ de bicromato de potássio a $27^{\circ} \mathrm{C}$

Palavras-chave: oocistos; Eimeria bateri; Eimeria uzura; Eimeria tsunodai; Eimeria fluminensis; Apicomplexa; Eimeriidae; codorna japonesa; Couturnix japonica; Rio de Janeiro; Brasil.

\section{Introduction}

Of cross breeding of some wild birds was appeared in Japan the Japanese quail, it has been given different contributions in all orient region in its genetic breeding. Today, this small bird has proved its commercial importance in producing eggs and meet (Corradelo, 1990). Above all, its importance as being an aviary model for biomedical researches (Ichilcik, Austin, 1978). Four distinct species of the genus Eimeria should be found in Coturnix japonica, E. bateri described in India by Bhatia et al., 1965; E. uzura by Tsunoda, Muraki, 1971; E. tsunodai by Tsutsumi, 1972, both in Japan, and E. fluminensis described previously by Teixeira, Lopes, 2000 as E. minima in Brazil. Being that, this research has as objectives to identify species of genus Eimeria parasites of $C$. japonica in Brazil, and including $E$. fluminensis in substitution of $E$. minima of the Japanese quail. Because of this species was preoccupied as E. minima Carvalho, 1943 of the Sylvilagus floridanus, the eastern cottontail rabbit.

\section{Material and methods}

The oocysts used in this work were obtained from feces samples from a group of 120 Japanese quail from a semi-

\footnotetext{
- Supported by CNPq

* Curso de Pós-Graduação em Ciências Veterinárias, UFRuralRJ, e-mail: teixeira@ufrrj.br *** Departamento de Parasitologia Animal, Instituto de Veterinária, Universidade Federal Rural do Rio de Janeiro, BR-465 Km 07 - CEP $23890-000$
Seropédica, RJ. Brasil. E-mail: lopescwg@ ufrri.br
} 
extensive breeding localized at municipality of Petrópolis in the State of Rio de Janeiro, Brazil. The animals were maintained at the W.O.Neitz Experimental Station in the Departamento de Parasitologia Animal, Instituto de Veterinária from the Universidade Federal Rural do Rio de Janeiro.

For the identification of the oocysts, these were obtained from fecal samples collected from the quails for a period of six consecutive days. After that, was used the technique of centrifugeflotation by using saturated sugar solution. After that, the samples contended oocysts were placed in bottles with potassium dichromate $2.5 \%$ at $27{ }^{\circ} \mathrm{C}$, and they were submitted to aeration by using an aquarium pump. After confirmed that $70 \%$ of the oocysts were sporulated, these ones were concentrated through the same centrifugefloatation technique with previously washing by PBS solution $\mathrm{pH} 7.0$ and they were left to centrifuge at $3000 \mathrm{rpm} / 10$ minutes. The concentrated oocysts were washed again in PBS, and latter they were storage in Eppendorf tubes under refrigeration at $4^{\circ} \mathrm{C}$.

The size of the esporulated oocysts and their morphologically description were done by support of a WILD-M20 microscope with ocular micrometry K-15X (PZO) with an objective of $1000 \mathrm{X}$. Using a JENAPOL/Karl Zeiss microscope with photographic $\mathrm{f}-\mathrm{KAS}$ Automatic2 camera, and Plu-X pan Kodak did photographs 125 ISO films.

Graph Pad Instat tm Copyright 1900-1994 Graph Pad Software V2-05 a 9504225 were used to obtained means, and standard deviation of the size of oocysts and sporocysts.

The nomenclature used in this work to classify the Japanese quail as Coturnix japonica was based on HOLE JR (2002)

\section{Results}

Four distinct species were found in the quail's feces, being that 50 esporulated oocysts were measured, being their measures and their respective morphological characteristics were described above:

Eimeria fluminensis for a preoccupied E. minima (Teixeira, Lopes, 2000) of the Japanese quail: Oocysts - spherical to subspherical from $17.31 \pm 1.87$ to $16,45 \pm 1,72 \mu \mathrm{m}$, and shape index of $1.05 \pm 0.04$. Oocist wall consisted of dabble layers, The alt layer was hyaline when the inner membrane was brownish. Polar granules were present, but micropila, polar cap and residual body of the oocyst were absents. Sporocyst was ovoid from $10.43 \pm 1.11$ by $5.92 \pm 0.58 \mu$ and shape index of $1.78 \pm 0.23$, with a discrete and a pyriform stieda body. Residual body of sporocysts was present with visible granulation.

A
Figures of the manuscript:
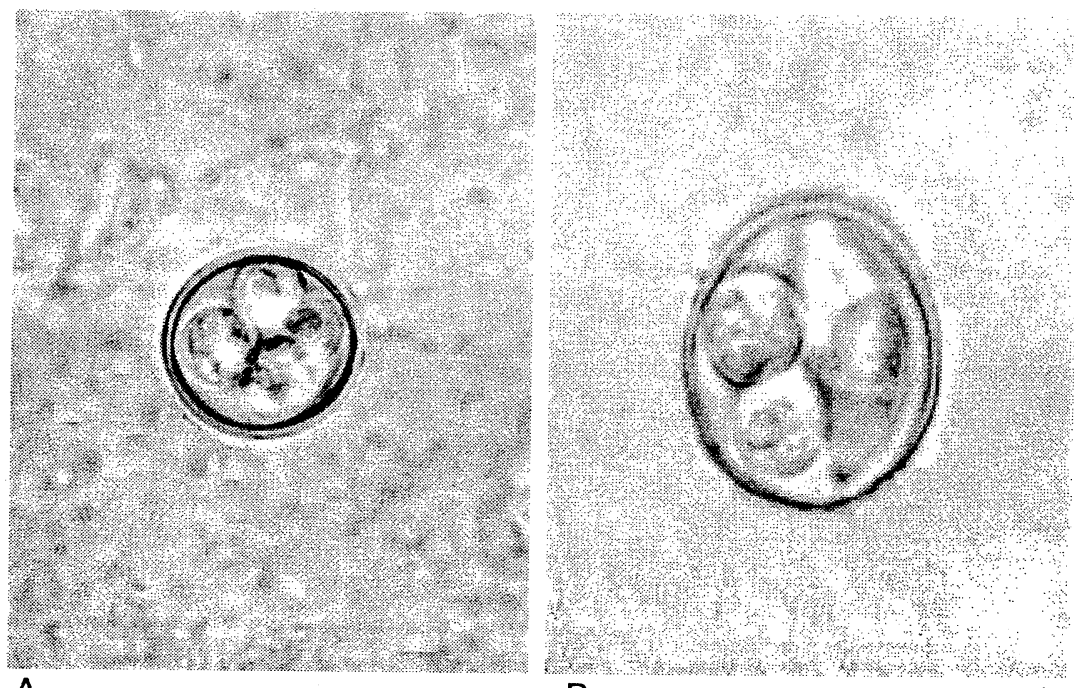

B

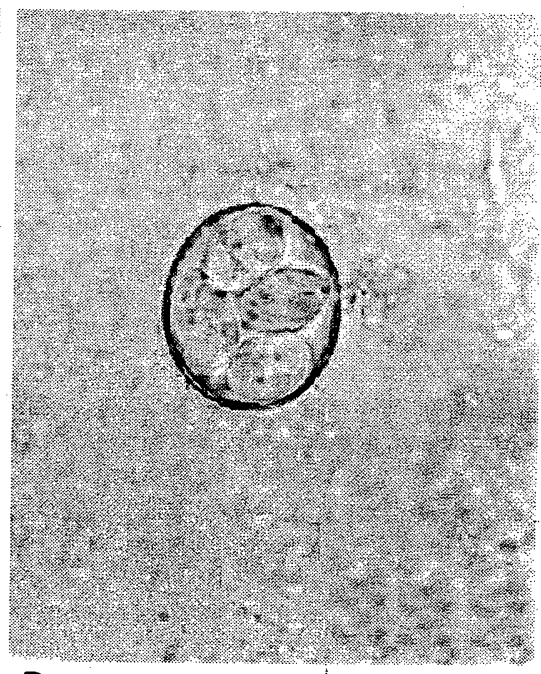

D

Figure 1: Sporulated oocysts. A- Eimeria fluminensis, B-E. tsunodai, C-E. uzura, D-E. bateri. Saturated sugar solution $(-=10 \mu \mathrm{m})$.

Each sporocyst had two sporozoites with polar globes of difficult visualization (Fig. 1A).

Eimeria tsunodai (Tsutsumi, 1972): oocysts ovoid from 19.85 $\pm 1,93$ to $15.55 \pm 1.50 \mu \mathrm{m}$, and shape index of $1.28 \pm 0.10$. Wall of the oocysts was consisted of two layers, the alt layer was hyaline, and the inner layer yellow-brownish. Polar granules were present in a reduced numbers. Micropila, polar cup and residual bodies were absent. Elongate sporocysts from 10.82 \pm 0.80 to $5.74 \pm 0.43 \mu \mathrm{m}$, and shape index of $1.89 \pm 0.14$. Residual body was granular with low density with two sporozoites with small polar globules (Fig. 1B).

Eimeria uzura (Tsunoda, Muraki, 1971): oocysts ovoid or rarely ellipsoidal from $20.2 \pm 1.78$ to $16.70 \pm 1.34 \mu \mathrm{m}$, and 
shape index of $1 \cdot 25 \pm 0,09$. Wall of the oocyst was consisted of two layers. The alt layer was hyaline when the inner was brownish yellow. Expressive polar granules, being so close give an aspect of a dense mass. Micropila, polar cup, and residual body were absent. Sporocyst was ovoid from 11.38 \pm 0.86 to $6.13 \pm 0.36 \mu \mathrm{m}$ with shape index of $1.98 \pm 0.84$. A knob shaped stieda body, and a granular residual body dense enough. Their sporzoites contained two rounded polar globules (Fig. 1C).

Eimeria bateri (Bhatia, et al., 1965): oocysts were ellipsoidal from $22.28 \pm 2.70$ to $1838 \pm 2.5 \mu \mathrm{m}$ and shape index of 1.22 \pm 014 . Wall of the oocysts was constituted of two layers with an alt layer hyaline and inner layer brownish yellow. Polar granules were present, but in reduced numbers which oftentimes represent a refractive structure under microscopic light. Micropila, polar cup, and residual bodies were absent. Sporocysts were ovoid from $10.86 \pm 0.90$ to $6.97 \pm$ $0.66 \mu \mathrm{m}$ with shape index of $1.57 \pm 0.12$ with a prominent stieda body, and their granular residual bodies were between their sporozoites. These sporozoites had polar globes well visible and ovoid discretely (Fig 1D).

\section{Discussion}

From the species more commonly related to $C$. japonica, one of these, $E$ bateri (Bhatia et al., 1965), was originally described in the gray quail, and the others $E$. uzura (Tsunoda, Muraki, 1971), E. tsunodai (Tsutsumi, 1972), and a more recently E. minima (Teixeira, Lopes, 2000) were described in Japanese quail; meanwhile, $E$. minima of the Japanese quail should be change to $E$. fluminensis, because the word was not described as species name in the genus Eimeria (Duszynski et al., 2001b). On the other hand, $E$. minima was a preoccupied species

$\left({ }^{*}\right)$ no indication
Table 1: Species of the genus Eimeria described for quails of the genus Cotunix

\begin{tabular}{|c|c|c|c|c|}
\hline \multirow{2}{*}{$\begin{array}{l}\text { Species } \\
\\
\end{array}$} & \multicolumn{2}{|c|}{ Oocysts $(\mu \mathrm{m})$} & \multirow[t]{2}{*}{ Sporocyst } & \multirow[t]{2}{*}{ Authors } \\
\hline & Means & S.I. & & \\
\hline E. bateri & $\begin{array}{l}23,00 \times 18,00 \\
23,30 \times 18,90 \\
22,28 \times 18,38\end{array}$ & $\begin{array}{l}1,26 \\
1,26 \\
1,22\end{array}$ & $\begin{array}{l}\text { ovoid } \\
\text { ovoid } \\
\text { elliptical }\end{array}$ & $\begin{array}{l}\text { Bhatia et al., } 1965 . \\
\text { Norton, Pierce, } 1971 . \\
\text { Present work. }\end{array}$ \\
\hline E. uzura & $\begin{array}{l}24,39 \times 18,66 \\
20,82 \times 16,70\end{array}$ & $\begin{array}{l}* c \\
1,25\end{array}$ & $\begin{array}{l}\text { ovoid } \\
\text { ovoid/ } \\
\text { elliptical }\end{array}$ & $\begin{array}{l}\text { Tsunoda, Muraki, } 1971 . \\
\text { Present work }\end{array}$ \\
\hline E. tsunodai & $\begin{array}{l}18,40 \times 14,10 \\
19,85 \times 10,82\end{array}$ & $\stackrel{*}{1,28}$ & $\begin{array}{l}\text { ovoid } \\
\text { ovoid }\end{array}$ & $\begin{array}{l}\text { Tsutsumi, } 1972 . \\
\text { Present work. }\end{array}$ \\
\hline E. fluminensis & $17,31 \times 16,45$ & 1,05 & $\begin{array}{l}\text { spherical } \\
\text { subspherical }\end{array}$ & Present work \\
\hline E. taldykurganica & $23,06 \times 12,39$ & 1,86 & ovoid & Svambaev, Utebaeva, 1971. \\
\hline E. tahamensis & $41,2 \times 28,40$ & 1,45 & ovoid & Amoudi, 1987. \\
\hline
\end{tabular}

described in the eastern cottontail rabbit (Sylvilagus floridanus) as E. minima Carvalho, 1943 (Duszynski et al., 2001a).

The identification of these species of Eimeria was difficult and was not a simples work as were mentioned before by Long, Joyner (1984), where the morphological description should be detailed, and in addition, should be considered the size and form of the oocysts, confirmed by statistic analysis preferentially. Of the inside, structures of the oocysts of the quails, polar granules were the great value for classification because of their distinct distribution in each species as well as the stieda bodies of each species with clear differences from it others.

In Table 1 was observed the comparison of different species of the genus Eimeria parasites of the genus Coturnix.

\section{Cited literature}

AMOUDI, M. A. Eimeria tahamensisn. sp. (Apicomplexa: Eimeriidae) from the Arabiam quail (Coturnix delegorguei arabica). Journal of Parasitology, v. 34, p. 455-456, 1987.

BATHIA, B. B.; PANDEY, T. P.; PANDE, B. P. Eimeria baterin. sp. from Indian common quail (Coturnix coturnix coturnix). Indian Journal of Microbiology, v. 5, p. 61-64, 1965.

CORRADELO, E. de F. A. Codorna máquina produtora de carnes e ovos. São Paulo: Ed. Ícone, 1990.

ICHILCIK, R., AUSTIN, J. C. The Japanese quail (Coturnix coturnix japonica) as a laboratory animal. Journal of South African Veterinary Association, v. 49, p. 203-207, 1978.

DUSZYNSKI, D. W.; UPTON, S. J.; COUCH, L. Coccidia (Eimeriidae) of Lagomorphs (hares and rabbits). Http://www.biology.unm.edu/biology/ coccidia/lagomorph. htm, 2001a.
DUSZYNSKI, D. W.; UPTON, S.;J.; COUCH, L. Coccidia of the world. http://www.biology.unm.edu/biology/coccidia. $h t m, 2001 b$.

HOLE JR., R. B. Galliformes species list. http://www.nmnh.si.edu/ BIRDNET/splists/Galliformescl.html. 7p., 2002.

LONG, P. L.; JOYNER, L. P. Problems in the identification of species of Eimeria. Journal of Protozoology, v. 31, p. 535-541, 1984.

NORTON, C. C.; PIERCE, M. A. The life cycle of Eimeria bateri(Protozoa: Eimeriidae) in the japanese quail Coturnix coturnix japonica. Journal of Protozoology, v. 18, p. 57-62, 1971.

SVAMBAEV, S. K., UTEBAEVA, M. K. [Coccidial infections of Phasianus cochicus mongolicus and Coturnix coturnix in Kazakhstan. Izevestia Akademi Nauk Kasakhstan, SSR. S. Biology], v. 6, p. 62-68, 1973. (in Russian)

TEIXEIRA, M.; LOPES, C. W. G. Eimeria miniman. sp. (Apicomplexa: Eimeriida $\epsilon$ ) from the Japanese quail (Cuturnix cuturnix japonica) in Brazil. Revista Brasileira de Ciência Veterinária, v. 7, p. 157-158, 2000. 
TSUNODA, L.; MURAKI, Y. A new coccidium of japanese quails: Eimeria uzura n. sp. Japanese Journal of Veterinary Science, v. 33, p. 227 $235,1971$.
TSUTSUMI, Y. Eimeria tsunodaisp. nov. (Protozoa: Eimeriidae) A caecal coccidium of Japanese quails (Coturnix cuturnix japonica). Japanese Journal of Veterinary Science, v. 34, p. 1-9, 1972. 